\title{
The effects of using American idioms in the development of the speaking skill in L2 students
}

\author{
Los efectos del uso de modismos estadounidenses en el desarrollo de la habilidad de \\ hablar en estudiantes de L2 \\ Os efeitos do uso de expressões idiomáticas americanas no desenvolvimento da habilidade \\ de fala em alunos $L 2$
}

ARTÍCULO DE INVESTIGACIÓN

Johanna Isabel Barriga Fray

johanna.i.barriga.f@pucesa.edu.ec

ORCID: 0000-0001-7995-6475

\author{
Michael John McCandless \\ mmccandless@pucesa.edu.ec \\ ORCID: 0000-0002-6904-1973
}

Pontificia Universidad Católica del Ecuador Sede Ambato, Ecuador

Recibido 03 de diciembre 2020 | Arbitrado y aceptado 18 de diciembre 2020 | Publicado en diciembre 2020

\section{RESUMEN}

There are thousands of non-native English speakers around the world. The use of a wide variety of dialects, registers, and other characteristics of language such as idiomatic expressions can cause lots of misunderstandings in people when they interact among one another. For that reason, American Idioms have to be taken into account as a crucial part in the development of English Language competence. It is a necessity that non-native speakers of English become aware and proficient in using English idiomatic expressions. However, many English learners, especially most of Ecuadorians, lack the competence to use them properly. This paper aims to show the effects of using American idioms in the development of speaking skills by L2 learners. Thereby, this research was carried out in a university in Ecuador with a population of 30 students. Quasi-experimental research was applied where one group was exposed to the language that native English speakers usually use. In addition, field research was carried out through instruments such as an observation checklist. Finally, the data analysis showed that those L2 students exposed to American idioms had subsequently increased their speaking skill.

Palabras clave: English learners; idioms; language; speaking skills

\section{ABSTRACT}

Hay miles de hablantes no nativos de inglés en todo el mundo. El uso de una amplia variedad de dialectos, registros y otras características del lenguaje, como las expresiones idiomáticas, puede causar muchos malentendidos en las personas cuando interactúan entre sí. Por esa razón, los modismos americanos deben tenerse en cuenta como una parte crucial en el desarrollo de la competencia en el idioma inglés. Es una necesidad que los hablantes no nativos de inglés se vuelvan conscientes y sean competentes en el uso de expresiones idiomáticas en inglés. Sin embargo, muchos estudiantes de inglés, especialmente la mayoría de los ecuatorianos, carecen de la competencia para usarlos correctamente. Este artículo tiene como objetivo mostrar los efectos del uso de modismos estadounidenses en el desarrollo de las habilidades del habla por parte de los estudiantes de una segunda lengua. De esta manera, esta investigación se llevó a cabo en una universidad de Ecuador con una población de 30 estudiantes. Se aplicó una investigación cuasiexperimental en la que un grupo estuvo expuesto al idioma que suelen utilizar los hablantes nativos de inglés. Además, La investigación de campo se llevó a cabo a través de instrumentos como una güía de observación. Finalmente, el análisis de datos mostró que los estudiantes de L2 expuestos a modismos estadounidenses habían aumentado posteriormente su habilidad para comunicarse de manera oral.

Key words: Estudiantes de inglés; expresiones idiomáticas; lenguaje; destreza del habla 


\section{RESUMO}

Existem milhares de falantes não nativos de inglês em todo o mundo. 0 uso de uma ampla variedade de dialetos, registros e outras características da linguagem, como expressões idiomáticas, pode causar muitos mal-entendidos nas pessoas quando elas interagem entre si. Por essa razão, American Idioms deve ser levado em consideração como uma parte crucial no desenvolvimento da competência da língua inglesa. É uma necessidade que falantes não nativos de inglês se tornem cientes e proficientes no uso de expressões idiomáticas em inglês. No entanto, muitos alunos de inglês, especialmente a maioria dos equatorianos, não têm competência para usá-los adequadamente. Este artigo tem como objetivo mostrar os efeitos do uso de expressões idiomáticas americanas no desenvolvimento da fala de alunos de L2. Desse modo, esta pesquisa foi realizada em uma universidade do Equador com uma população de 30 alunos. Uma pesquisa quase experimental foi aplicada onde um grupo foi exposto ao idioma que os falantes nativos de inglês costumam usar. Além disso, a pesquisa de campo foi realizada por meio de instrumentos como o checklist de observação. Por fim, a análise dos dados mostrou que os alunos L2 expostos a expressões idiomáticas americanas aumentaram posteriormente sua habilidade de fala.

Palavras-chave: Aprendizes de inglês; expressões idiomáticas; língua; Habilidades de fala

\section{INTRODUCCIÓN}

Latin America, as a region, is below the world average in the English First English Proficiency Index (EF EPI) in all age groups(Cronquist \& Fiszbein, 2017), which indicates a clear deficiency in the acquisition of the English language.

In Ecuador, for example, the standards that should be reached according to the Common European Framework of Reference for Languages (CEFR), are still below the levels established. According to reports by the EF EPI, in 2015 Ecuador was in position 38 among 70 countries. However, in 2019 we ranked 81st out of 100 countries, with Ecuador being the worst country in Latin America since it ranked 19th out of 19 countries according to EF EPI.
Actually, second language learners in Ecuador have a deep lack of formal and informal vocabulary, due in part to the low motivation at the moment to learn English since they do not find it attractive or useful to learn any other language in addition to their native Spanish.

Nevertheless, it is also evident that a language will certainly undergo variations over the years, variations that are related to the age and the social conditions where every individual grows up. This relationship among people and the social surroundings where they live cause a broad list of informal expressions that no longer follow any specific linguistic pattern. In other words, these sociolinguistic variations may obstruct nonnative speakers or learners from acquiring a second language effectively.

This research has emerged with the essential aim to boost speaking skills of nonnative speakers of English through the use of idiomatic expressions that are often used in everyday situations.

According to Ambrose (2003), understanding the lexicon of English demands more than knowing the denotative meaning of words. It requires its speakers to have connotative word comprehension and understanding of figurative language, and idioms fall into this final category.

Nonetheless, the interest to analyze this phenomenon has only increased in the last few years. Therefore, this research proposes a scientific problem: How can the use of American idioms enhance the development of speaking skills in second language learners? 


\section{Importance of the problem}

The current investigation shows that idioms constitute as an important chunk of the language that comprehends a wide variety of informal and creative expressions that play a crucial role within specific social groups. The use of idioms tries to strengthen social identity with the intention to encourage a sense of familiarity. Because of its various objectives, idioms can be useful in different extents such as sociolinguistics, and education.

Nevertheless, the study of idioms is often forgotten and misjudged mostly because the casualness of its expressions makes researchers think it does not deserve a deep investigation. It's worth mentioning that I have noticed that non-native learners struggle at the moment of dealing with informal lexes no matter the situation, such as at the moment to keep a conversation with foreigners, when watching series or movies in English, and even at the time to listen to music. Subsequently, the communication among speakers is beyond question locked due to the dispute that these sociolinguist distinctions produce.

The lack of instructor competence in the use of informal phrases, which contributes to a total misunderstanding of the language, is possibly among some of the limits that restrict learners to communicate, listen, understand and use idioms. For this reason, the main aim of this research is to establish how the students of third level improves their speaking skill after using idioms.

(Oakhill, 2016) stated that in Detroit, the use of idiomatic expressions was almost the same in higher status institutions and lower status institutions. By using these informal phrases, both males and females in the lowerstatus community seemed to interact. However, males used these only with other males in the higher-status group, while females did not seem to use them at all. It can also be said that during adolescence, the use of idioms is established.

Although there are groups that share a specific way of speaking, it is the educational background and the social context that certainly affect any language (Booij, 2007). Therefore, there is a tendency to use words that are rarely used by those who have completed their primary and secondary education if we compare individuals who dropped school at an early age.

Individuals who have common values, characteristics and attitudes with the intention of differentiating from others may use the expressions described above. These terms can be seen as describing teenagers who want to demonstrate their sovereignty. These groups can feel that they speak an authentic and original language through idiomatic expressions. The new attractive" types were replaced by terms such as stunning, handsome, good-looking or hunk. (Liu, 2017)

The study of the relationship between language and culture is discussed by sociolingüistics. We all know that nobody in every case talks in the same way. We understand that in the speech of certain people in society, certain uses of language such as idioms may be found. We also know that while people live in the same place, what distinguishes their way of speaking is their education and economic status. These differences can in fact, be used to suggest membership in various social classes. (Alamri, 2018)

For this reason, the influence of American idioms on the development of speaking skills in L2 students from the third level of Lingüistic Competences Coordination, School of Education, Humanities and Technologies at UNACH, located in the city of Riobamba, during the term April-September 2020 is intended to be seen in this report. 
It was important to establish a strategy to achieve the goals specified in order to undertake the present research, as any study applies scientific measures that lead to a better understanding of facts.

According to Gutiérrez (1996) and in order to present a consistent view of the issue, a qualitative and quantitative approach were used and a mixed model reflects a higher range of interaction between a qualitative and quantitative approach. During the entire process, or at least some of its phases, both of them should be combined. These two methods require good control, plus a versatile mindset.

Additionally, it was a bibliographic investigation as many references were consulted such as: textbooks, legal and authorized documents that support the conceptual framework and the statistics.

It was a quasi-experimental study, according to the goals and characteristics of this study, because it began with a conceptual investigation of real facts along with the creation of strategies based on the experience obtained by teaching staff in the area of sociolinguistics.

\section{METHODOLOGY}

The current investigation was intended to measure the effects on comprehension and use that result from the explicit teaching of American idioms to L2 students. The research was based on the quasi-experimental category, because it permited to do an observation before and after the application of idiomatic expressions, this enabled to include instruments of data collection.

After the observation was done, the improvement or the effects of American idioms on second language learners at Unach were described, thus, the researcher used an explicative-descriptive research.

Additionally, a field study was applied since it occurred where the events took place, that is to say, at the third level students in the Lingüistic Competences Coordination, Faculty of Education at Universidad Nacional de Chimborazo, located in the city of Riobamba, Ecuador during the period April - September 2020. Hence, this research was carried out in the educational field.

\section{Population}

In this study according to the established objectives, the third level students in the Lingüistic Competences Coordination, Faculty of Education at UNACH were considered.

\section{Sample}

A sample was not necessary since all the participants were part of the study in order to reach real results.

\section{Research Method}

Also, the researcher applied the Hypothetic - Deductive method. This method constituted itself as the proper mechanism to be applied in the process because of the researcher began from the problem, then its observation, the theoretical framework was analyzed and finally the conclusions were presented.

\section{Techniques and instruments to collect data}

It is important to mention that the observation technique was used, because it appreciates the incidence of the application of the American idioms on second language learners. So, the intrument used was an observation checklist at the beginning and at the end of the study.

\section{RESULTS}

As the objective of this research was to measure the effects on comprehension and use that result from the explicit teaching of 
American idioms to L2 students, the data was obtained through observation guides at the beginning and at the end of the investigation which were applied in the third level students in the Lingüistic Competences Coordination, Faculty of Education at Universidad Nacional de Chimborazo, Ecuador during the period April - September 2020, this process helped to measure the effects that American idioms have on second language learners.

The study confirmed that after the application of American idioms in the class, the students were skilled to include these new terms when they interacted with others. In pair work, for example, students could have a short conversation, but this time they shared information using these new terms, contrary to the beginning research, where students said that in their primary and secondary education the students were only taught English as a second language with a traditional textbook that never included an informal expression. Figure 1 below shows the findings prior to the application of the American idioms.

\section{RECALLS AND REPLACES STANDARD LEXIS WITH AMERICAN IDIOMS}

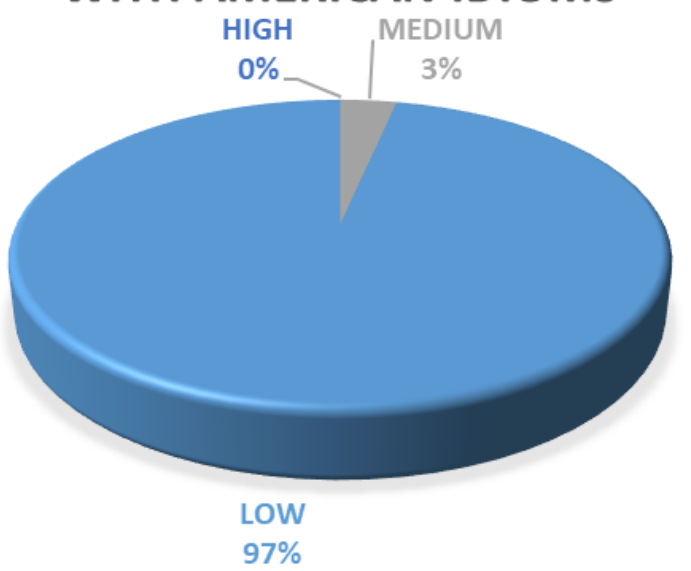

Figure 1. Recalls and replaces standard lexis wiyh American idioms

\section{Analysis}

It can be found that 29 out of 30 students in a pair work exercise could not remember and substitute standard terms with idiomatic expressions before the application of American idioms just a single student who was able to do it.

\section{Interpretation}

It can be said that the identification and substitution of standard terms by idioms are difficult. It is also clear that students have no power over informal phrases that obstruct communication and hinder learning.

On the other hand, the observation checklist aimed at third-level students from the Lingüistic Competences Coordination at the UNACH School of Education located in Riobamba, after the application of American idioms, term April - September 2020 showed that these students were able to use and understand idiomatic expressions used in various tasks as shown in figure 2 below. 


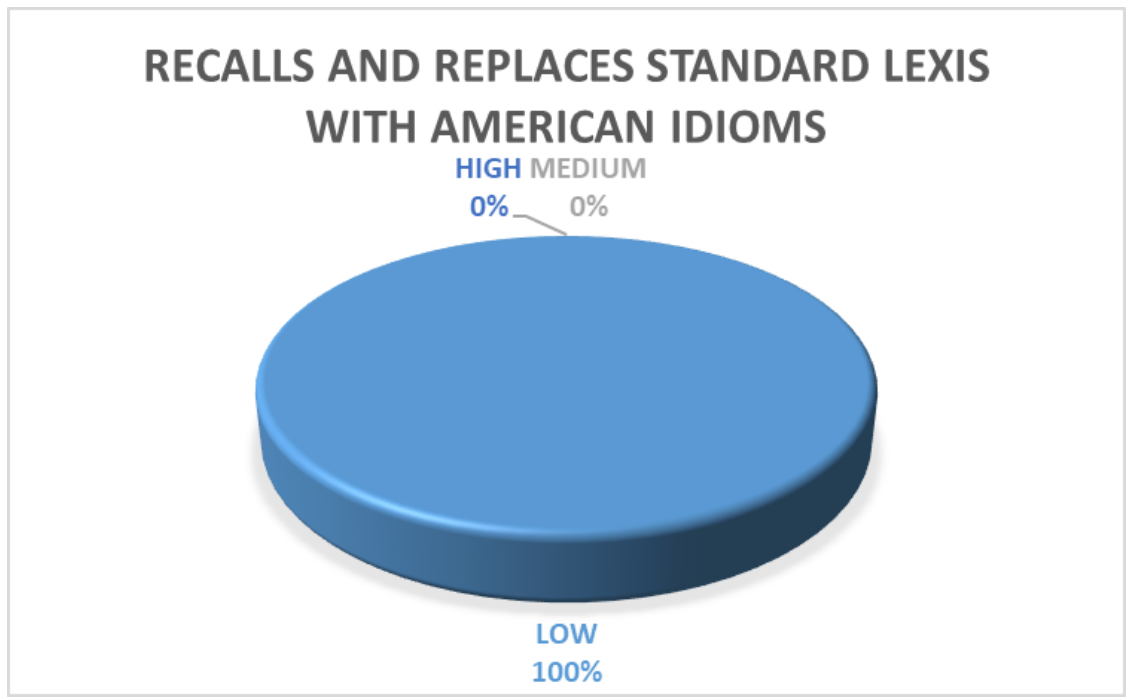

Figure 2. Recalls and replaces standard lexis wiyh American idioms

\section{Analysis}

It can be noted that the total population was able to replace terms they know with idiomatic expressions due to the application of American idioms in the class.

\section{Interpretation}

The students have clearly gained basic knowledge and comprehension of idiomatic expressions to be implemented in future situations.

\section{Discussion}

These findings have helped us to enrich the learning experience of students from various sociolinguistic backgrounds (Holmes, 2013).

First of all, to do this, it was found that idiomatic expressions are an integral part of the language that comprises a wide variety of specific expressions that take an active part in a certain social community. (Aimin, 2013) To foster a sense of informality, the use of American idioms is intended to strengthen social identity. It is possible to apply idioms in various areas of expertise because of their different areas.
According to Vasiljevic (2011), in the field of EFL, idiomatic language has been a neglected area of vocabulary instruction. Although nobody doubts the advantages of studying idioms or teaching them, teachers have been at a loss for several years as to how to help their students develop idiomatic expressions.

This research will be seen as a creative and avant-garde proposal with a strong social and educational effect, and as a tool to support that will eventually enhance the teaching and learning process of English as a second language.

\section{CONCLUSIONS}

Some conclusions have been formulated on the basis of the results obtained during the entire phase of the current study.

The focus in education is on moving away from the learning of language to one of communicative competence. This concentrate on communicative competence and language's social function has led to a concern about linguistic suitability rather than precision (Guduru, 2012). 
It was possible to verify that the incorporation and use of American idioms had an important effect on the acquisition of a second language, with a substantial increase in the learners' oral production.

The interaction and sociolingüistic comprehension of the English language of third-level UNACH students has been dramatically improved by the implementation of clear and brief meanings, since they provided the meaning of non-traditional terms in the multiple activities indicated in the study, taking into account that 29 out of 30 students were able to recall and substitute basic lexis for American idioms.

\section{REFERENCES}

Aimin, L. (2013). The study of second language acquisition under socio-cultural theory. American Journal of Educational Research

Alamri, W. A. (2018). Communicative Language Teaching: Possible Alternative Approaches to CLT and Teaching Contexts. English Language Teaching, 11(10), 132. https://doi.org/10.5539/elt.v11n10p132

Ambrose, J. (2003). Why Idioms Are Important for English. 180-182

Booij, G. (2007). The Grammar of Words: An Introduction to Linguistic Morphology.
Oxford University Press, 2nd Edition. Retrieved from https://n9.cl/me0fz

Cronquist, K., \& Fiszbein, A. (2017). El aprendizaje del inglés en América Latina. El Aprendizaje Del Inglés En Amércica Latina, 1-88. Retrieved from https://www.thedialogue.org/wpcontent/uploads/2017/09/El-

aprendizaje-del-inglés-en-América-Latina1.pdf

Guduru, R. (2012). Learning Academic Idioms Some Useful Techniques for Beginner Learners. Language in India, 12(2), 484494

Gutiérrez, L. (1996). Paradigmas Cuantitativo y Cualitativo en la Investigación socioeducativa: Proyección y Reflexiones. Paradigma, 14

Holmes, J. (2013). An introduction to sociolinguistics. Routledge

Liu, D. (2017). Idioms: Description, comprehension, acquisition, and pedagogy. Routledge, 208

Oakhill, J. (2016). Understanding of idiomatic expressions in context in skilled and lessskilled comprehenders: Online processing and interpretation. Scientific Studies of Reading, 34

Vasiljevic, Z. (2011). Using conceptual metaphors and L1 definitions in teaching idioms to non-native speakers. Journal of Asia TEFL, 8, $N^{\circ} 3$ 